\title{
The Effect of Tourism Competitiveness relating to Tourist Arrivals and Revenue in
}

\section{East Asia}

\author{
Ming-Lang Yeh ${ }^{1}$ \\ ${ }^{1}$ Assistant Professor of the Department of Business \\ Administration of Chung Hua University, Taiwan \\ mlyeh@chu.edu.tw ${ }^{1}$ \\ Hsieh,Ya-Ju ${ }^{3}$ \\ ${ }^{3}$ The Department of Hospitality Management Assistant, Chung \\ Hua University, Taiwan \\ reachhrm@chu.edu.tw ${ }^{3}$
}

\author{
Lai-Chu Lin $^{2 *}$ \\ ${ }^{2}$ Ph.D Student of Business Administration Group of Technology \\ Management, Chung Hua University, Taiwan \\ gov310@mcc.gov.tw ${ }^{2}$
Chin-Hsin $\mathrm{Chiu}^{4}$
${ }^{4}$ Ph.D. Program of Technology Management, Chung Hua University, Taiwan chiutiffany2002@yahoo.com.tw ${ }^{4}$

\begin{abstract}
Tourism industry has been growing in recent years, thus becoming a highly competitive market. Government improves its tourism competitiveness to attract a large amount of foreign tourists, increase tourist revenue, and create local employment opportunities. Studies of tourism competitiveness abroad began in the 1990s, with the construction of competitive models, and the development of indexes and relevant empirical researches that are getting more sophisticated. Tourism competitiveness abroad can be divided into two categories. One approach is that researchers develop a set of indexes for tourism owners to evaluate the country's relative strengths based on the 7-point Likert scale. The other approach is aimed at calculating the tourism competitiveness comprehensive index. Case studies of tourism competitiveness are often restrained by high survey costs. The report from World Economic Forum 20010 - 2012 considered the deferred effect and used the statistical data from World Tourism Organization of United Nations from 2010 to 2012. This research explored the important indexes that affect the amount of foreign tourists and revenue in twelve nations in East Asia. This study revealed the dominant indexes affecting tourist arrivals and tourist revenue in East Asia indude national safety and security, tourism infrastructures and cultural resources. The results can be applied to tourism industry and developing tourism strategy.
\end{abstract}

\section{Keywords- The Travel \&Tourism Competitiveness Index (TTCI), Multiple Regression Analysis, National Economic Benefits}

\section{INTRODUCTION}

The joy of exploring new countries is nearly everyone's dream. The World Tourism Organization (UNWTO) statistics show that from 1950 to 2012 global international tourist numbers grew from 25 million to 980 million, increasing 38 times. Although it was unfavorable in 2012 and faced global econo mic stagnation, political instability in the Middle East and North Africa as well as the earthquake tsunami disaster in Japan, it increased with $4.4 \%$ growth over the previous year. Regarding society and economic development, tourism has become one of the enterprising trends in the world economy, with the biggest effect in the industries. Tourism development not only attracts foreign touris ts to increase touris $m$ revenue and revive the economy, but also creates more employment opportunities and enhances citizens' quality of life.

National tourism competitiveness issues are gradually becoming increasingly fierce in the tourism market [4]. Considering the tourism competitiveness since 1990, this type of research can be divided into two approaches, with the first approach being a set of indicators listed by the seven-point Likert scale. This assesses the comparative advantage to competitors in a particular country [5]. The second approach calculates the tourism competitiveness index since 2007 by the World Economic Forum (WEF, 2013) as published by the global touris $m$ report from Travel and Tourism Competitiveness Report (TTCR, 2013). It covers a broad spectrum of touris $m$ destination competitiveness surveys [2].

It indicates that according to their assessment of the Travel \& Tourism Competitiveness Index (TTCI), it includes national policy, environmental protection, public security, health, infrastructure, human resource, natural and cultural resource. In their 2009 report, there are 44 indicators that are calculated based on the actual data (hard data), the data sources, including (UNWTO), [14]. International Air Transport Association (IATA), World Health Organization (WHO), United Nations Educational, Scientific and Cultural Organization (UNESCO), Conference on Trade and Development (UNCTAD). The other 29 indicators were lacking in substantive information according to the survey data. This report shows the current situation appraisal as it refers to countries tourism competitiveness and also presented competitions of national tourism development strengths and weaknesses, in future 
decision-making regarding improvement in the tourism industry.

Strategy planning for increasing touris $m$ and the competitive advantage in the tourist market is crucial. By 2010, international tourist statistics show that the number of travelers reached approximately 204 million people in Asia and the Pacific region, the second highest in the world after Europe. In East Asia (Northeast Asia and Southeast Asia) tourism travel show 181 million passengers, up $19.3 \%$, ranking the highest in the global tourism market [11]. In terms of average annual gro wth rate in East Asia it indicates a growth rate of $6.8 \%$. Therefore, East Asian countries travel more than other countries in the world, making the prospect for the development of the tourism industry a high priority.

Analysis of national competitive positioning in the tourism market is a very important issue, but more importantly, is how to increase the number of tourist visitors and thereby increasing tourism income [6]. In a March 2011 report released by the World Econo mic Forum (WEF), [13], Travel and Tourism Competitiveness Report (TTCR) tourism competitiveness ranking increased in 2008. In 2010 tourism revenue was $\$ 8.7$ billion, in the East Asian region, but it is still lower than the $\$ 50.1$ billion in China, $\$ 27$ billion in Hong Kong, \$23.4 billion in Thailand, \$18.3 billion in Malaysia, \$15.3 billion in Japan, \$14.1 billion in Singapore, and $\$ 13.8$ billion in South Korea.

This research, according to Travel and Tourism Competitiveness Report (TTCR) result extension of applications using multiple regression analysis, helps the tourism managers understand those indicators which reflect sightseeing number of visitors and tourist revenues with significant relation to tourism managers to make the m more aware of decision-making information.

\section{LITERATURE}

The words 'travel' and 'tourism' are often interchangeable. They usually refer to the research field for human resources, social commercial activities, business purposes, or leisure and personal pleasure [7]. People engaged in touris $m$ activities go or stay for a short period of time in a place other than their daily living environment, combining recreational or other purposes of the World Tourism Organization. Travel may consist of a job related destination required by a business. W. Hunziker [1] pointed out, based on foreigners' tourism, the person will probably will stay somewhere for a short period of time doing a variety of activities. This will include travel and lodging but will not lead to permanent residence, and has nothing to do with any business activities. They [3] defined sightseeing as people moving from one place to another in a short period of time. This includes the three basic concepts of demand, supply, and links. The tourism industry covers catering, hotel accommodations, transportation, and many other aspects of the industry including frequently requested activities by tourists [8]. It is the desire of every country's tourism department that it will be able to increase travel consumption, boost their economy, and add to desirable local opportunities [10] In general, further the economic contribution that tourism adds to the well being of the citizens of their country. [2]. Although the tourism industry is invisible, it is valuable.

Sightseeing areas definitely impacts local prices. Location has a direct effect on the price of tour packages [12], especially around holidays. A local business as well as the government feels the effect of tourism as it increases their income [9].

In the $21^{\text {st }}$ century, many people are interested in touring diffe rent places. Some tour experiences are life changing as people seek to fulfill fantasies, increase their positive attitude by feeling good about themselves and just have fun [7].

Tourist experiences touch all five human senses which are sight, hearing, smell, taste, and touch. This leads to a deeper conceptualization of sensory dimension when it involves touring new places [3]. The facilitation of extraordinary experiences has become a desired goal in the tourism industry [12].

Understanding the value of touris $m$, it should be pointed out that the analysis of sightseeing and tourism in general demand greater development of the industry resulting in specific tourist destinations, as well as tourism market preferences.

\section{METHODOLOGY}

According to the World Economic Forum(WEF, 2013) from 2009 to 2012, and using those three years as independent variables, Travel \& Touris m Competitiveness Index (TTCI, 2013) explained the deferred effect in from 2010 to 2012 regarding three sightseeing statistics. The number of tourist visitors and tourism revenue were two of the indicators of the dependent variable. The research framework was divided into two steps. Step one: Explore the significant corre lation of the sightseeing competitiveness indicators of East Asian countries and tourism revenue with the synopsis shown in Figure 1 The research proposes the following as sumptions:

H1: Touris mord inance, environ ment infrastructure and sightseeing, have the significant positive relationship to tourists and income.

$\mathrm{H} 2$ : Touris m ord inance, environ ment infrastructure and sightseeing, income has a significant positive relationship. 


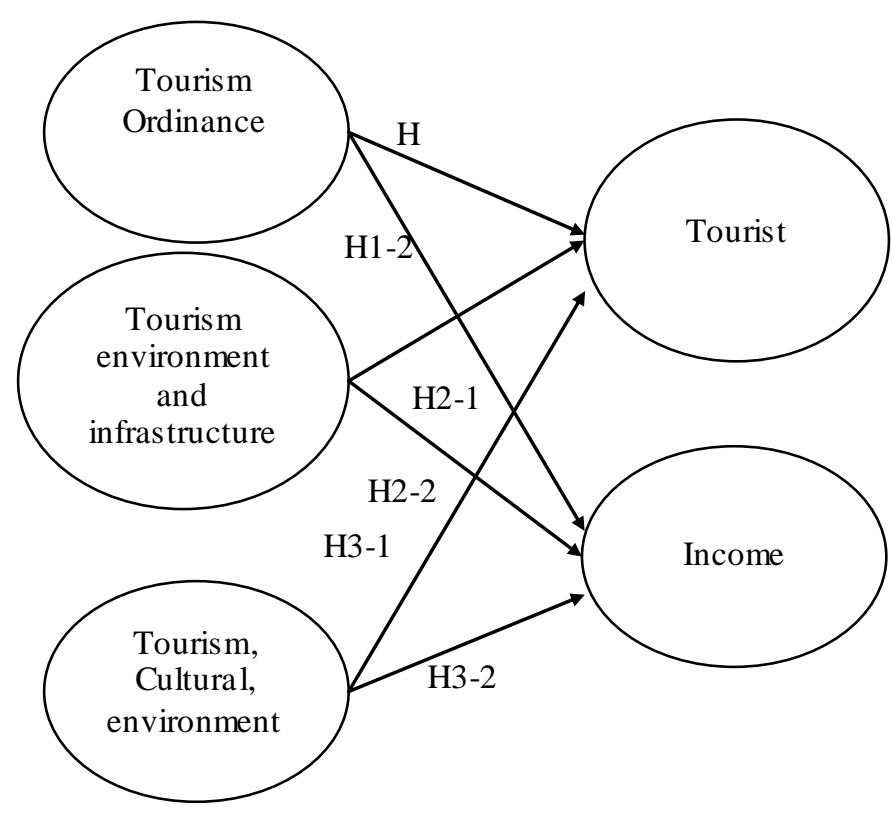

Figure 1 Research framework

\section{RESULT}

The World Economic Foru m (WEF, 2013) research is based on the Travel \& Tourism Competitiveness Index (TTCI, 2013) indicators and uses statistic multiple regression analysis. It shows the number of tourists and the amount of tourism income in East Asian countries, concluding that the tourism market is a good business and the current numbers of sightseeing tourists are a profitable situation.

The "push" factor refers to the tourist's travel motivation and explores the reason for traveling, such as the pursuit of leisure, relaxation, an escape from pressure and stress, or perhaps the pursuit of novelty and excitement. The "pull" in the research results refers to the number of tourist visitors and tourism income competitiveness indicators in East Asia. This is explained the three main points below:

(1) National safety and security: a variety of threats, risks, and a potential crisis will affect the tourist's sightseeing travel tendency. For example, surrounded by "Yellow-RedShirts" in Thailand's Bangkok International Airport event in 2008 and 2010, Hong Kong's H1N1 influenza pandemic of 2009 and 2011, and Japan's Fukushima nuclear disaster events resulted in fewer tourists. Because of security considerations these events prohibit its own nationals, chosen by the country for sightseeing, from $\mathrm{v}$ isiting other countries. Also, the possibility of terroris $m$, robbery, kidnapping for ransom, crime and violence will directly affect the tourist passenger's travel attitude resulting in possible damage to the country's economic interests in the tourism industry. Tourism safety is a very important issue for tourists, especially when negative events are reported in the media and it undoubtedly will directly affect the national tourist arrivals and tourism income.

(2) Touris $m$ infrastructure: Current Internet popularity has resulted in more and more tourists using it to research information before making their travel plans. They are able to find competitive prices for airfare, hotels, food, souvenirs, and related travel services and/or products. For the travel industry, the tourist infrastructure is very important in developing their tourism strategy, and actively improving their touris $m$ infrastructure environment.

(3) Cultural Resources: In order to encourage tourism, it is important to increase the attractiveness of the tourist's destination. As traveler's activities and product consumption increase, the revitalization and development of the tourism industry or region also needs to increase. That includes a combination of cultural resources, products, festivals, activities and events, in order to insure that the tourist finds the experience to be exciting, fun and happy, resulting in achieving many different sources of income. In the future development of cultural resources, it would be beneficial to strengthen its unique tourist destination to create a stunning atmosphere without being imitative. Not only would that meet the expectations of the tourists, but also by doing this they could look forward to increasing the number of travelers, because they would like to visit there again.

Table 1 Asia tourism income from 2010 to 2012

\begin{tabular}{|c|c|c|c|c|c|c|c|c|c|}
\hline \multirow{2}{*}{ Countries } & \multicolumn{3}{|c|}{2010} & \multicolumn{3}{|c|}{2011} & \multicolumn{3}{|c|}{2012} \\
\hline & Original & Rate & Ratio & Original & Rate & Ratio & Original & Rate & Ratio \\
\hline Taiwan & 5,936 & 87 & 83 & 6,816 & 100 & 84 & 8,719 & 128 & 111 \\
\hline $\begin{array}{l}\text { Hong } \\
\text { Kong }\end{array}$ & 20,269 & 99 & 105 & 20,418 & 100 & 101 & 27,028 & 132 & 136 \\
\hline Japan & 13,781 & 110 & 108 & 12,537 & 100 & 97 & 15,356 & 122 & 119 \\
\hline Korea & 13,479 & 100 & 91 & 13,304 & 99 & 91 & 13,805 & 102 & 96 \\
\hline Indonesia & 8,150 & 135 & 112 & 6,054 & 100 & 73 & 7,618 & 126 & 94 \\
\hline Thailand & 22,497 & 116 & 105 & 19,421 & 100 & 86 & 23,407 & 121 & 106 \\
\hline Vietnam & 3,930 & 129 & 96 & 3,050 & 100 & 71 & 4,450 & 146 & 107 \\
\hline Cambodia & 1,398 & 107 & 77 & 1,312 & 100 & 66 & 1,412 & 108 & 73 \\
\hline Philippines & 3,024 & 106 & 79 & 2,853 & 100 & 73 & 3,228 & 113 & 83 \\
\hline Singapore & 10,711 & 114 & 120 & 9,383 & 100 & 100 & 14,181 & 151 & 157 \\
\hline Malaysia & 15,293 & 97 & 92 & 15,798 & 100 & 92 & 18,315 & 116 & 108 \\
\hline China & 44,130 & 100 & 78 & 42,632 & 97 & 78 & 50,154 & 114 & 97 \\
\hline
\end{tabular}

Unit: million dollars 


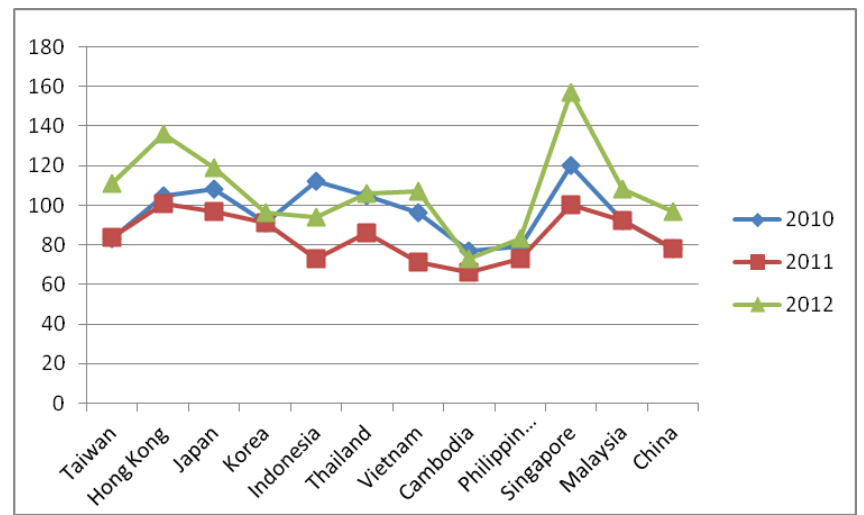

Graph 1 Asia touris m income from 2010 to 2012

Travel \& Touris m Competitiveness Index [14] pointed out

1. Policy rules and regulations

1.1 Prevalence of foreign ownership

Q: Fo reign ownership of companies in your country

1.2 Property rights

Q: Property rights in your country, including over financial as sets

1.3 Business impact of rules on FDI

Q: In your country, rules governing foreign direct investment

1.4 Vis a require ments

Q: Number of countries whose citizens are exempt from obtaining a visa $(=1)$ or able to obtain one upon arrival $(=0.5)$ out of all UN countries .

1.5 Openness of bilateral Air Service Agreements

Q: Index of openness of bilateral Air Service Agreement.

1.6 Transparency of government policy making

Q: A re firms in your country usually informed clearly by the government of changes in policies and regulations affecting your industry?

1.7 Time required starting a business

Q: Nu mber of days required to start a business.

1.8 Cost to start a business

Q: Cost to start a business as a percentage of GNI per capital (2008).

2. Env iron mental sustainability

2.1 Stringency of environ mental regulation

Q: How stringent is your country's environmental regulation?

2.2 En force ment of environ mental regulation

Q: Enforcement of environmental regulation in your country

2.3 Sustainability of T\&T industry development

Q: Is your country's government taking the necessary steps to ensure that the Travel \& Tourism sector is being developed in a sustainable way?

2.4 Carbon dioxide emissions

Q: Carbon dioxide e mis sions per capita in metric tons.

2.5 Particulate matter concentration
Q: Urban population-weighted PM10 micrograms per cubic meter (2005).

2.6 Threatened species

Q: Threatened species as a percentage of total species (2008).

2.7 Environmental treaty ratification

Q: Total nu mber of ratified environ mental treaties .

3. Safety and security

3.1 Business costs of terrorism

Q: The threat of terrorism in your country

3.2 Re liability of police services

Q: Police services in your country

3.3 Business costs of crime and violence

$\mathrm{Q}$ : The incidence of common crime and violence in your country.

3.4 Road traffic accidents

Q: Estimated deaths per 100,000 populations due to road traffic accidents

4. Health and hygiene

4.1 Physician density

Q: Physician density per 1,000 people or most recent year availab le

4.2 Access to improved sanitation

Q: Access to adequate sanitation as a percentage of total population

4.3 Access to improved drinking water

Q: Access to safe drinking water as a percentage of total population.

4.4 Hospital beds

Q: Hospital beds per 10,000 populations.

5. Prioritization of Travel \& Touris $m$

5.1 Govern ment prioritization of the T\&T industry

Q: The development of the Travel \& Tourism industry is a priority for the government of your country

5.2 T\&T government expenditure

Q: T \& $\mathrm{T}$ government expenditure as a percentage of total budgets.

5.3 Effectiveness of marketing and branding to attract tourists

Q: Does your country carry out effective marketing and branding to attract touris ts?

5.4 T\&T fair attendance

Q: Index of country presence at 13 major T \& T fairs .

The Travel and Tourism Competitiveness Report (WEF), [13].

\section{CONCLUSION}

The tourism industry has become one of the world's largest businesses as worldwide travel becomes more and more prevalent. Many countries are actively developing its touris m industry in order to increase their national econo mic condition. However, touris $\mathrm{m}$ needs to be interdisciplinary, combining many different factors. The number of tourists and the volume of tourism income is used as an indicator to 
confirm the tourism competitiveness index and how it relates to the impact of the significant number of visitors and tourism revenue of the East Asian countries as tourists visit for sightseeing. The results are used to develop the strategy that the tourist industry will use to encourage and increase tourism.

Tourism must be combined with a variety of products and experience which affects each country. Tourism motivation is quite complex and sometimes conflicting and that results in what is referred to as "push and pull factors". Although it is the role of tourism motivation, which might include freedom from normal day to day stress, relaxation or just for pleasure, this research is limited regarding the factors that hinder touris m opportunities.

From National safety and security: a variety of threats, risks, and a potential crisis will affect the tourist's sightseeing travel tendency. Tourism infrastructure: Current Internet popularity has resulted in more and more tourists using it to research information before making their travel plans. Cultural Resources: In order to encourage tourism, it is important to increase the attractiveness of the tourist's destination.

Because world-wide travel is becoming more and more common, the tourism industry has developed into a multimillion dollar business. Every country hopes to capitalize on it by increasing their tourism industry. As people explore the most frugal method of travel, somewhere there will be a travel office offering exactly what they are looking for.

\section{REFERENCES}

[1] Crouch, G. I. (2010). Destination Competitiveness: An Analysis of Determinant Attributes. Journal of Travel Research, 50, $27-45$.

[2] Das, J., \& DiRienzo, C. E. (2009). Global Tourism Compet it iness and Freedom of the Press. Journal of Travel Research, 47(4), 470-497.

[3] Dora Agapito, Julio Mendes, Patricia Valle (2013), Exploring the conceptualization of the sensory dimension of tourist experiences. Journal of Destination Marketing and Management. http://dx.doi.org/10.1016/i.jdmm.2013.03.001

[4] Enright, M. J., \& Newton, J. (2005). Determinants of Tourism Destination Competitiveness in Asia Pacific: Comprehensive and Universality. Journal of Travel Research, 43, 339-350.

[5] Gomezelj, D. O., \& Mihalic T. (2008). Destination competitivenessApplying different models, the case of Slovenia. Tourism Management, 29, 294-307.

[6] Hall CM, Page SJ. (2002). Managing Urban Tourism Pearson Education: Harlow.

[7] Holbrook, M., and Hirschman, E. (1982). The experiential aspects of consumption: consumer fantasies, feelings and fun. Journal of Consumer Research, 9(2), 132-140.

[8] Jennifer Blanke and Thea Chiesa (2013). Tourism Competitiveness Report 2013: Reducing barriers economic growth and job creation. Travel \& Tourism Competitiveness Index (TTCI, 2013). http://www3.weforum.org/docs/WEF TT Competitiveness Report 2 $\underline{013 . p d f}$

[9] Joaquin Alegre, Magdalena Cladera, Maria Sard (2013), Tourist areas: Examining the effects of location attributes on tour-operator package holiday prices. Tourism Management. Vol.38., pp.131-141.

[10] Page S. (1995). Urban Tourism. Routledge: London.
[11] Tourism Bureau (2013). Tourism Burea, Rep. of China (Taiwan) www.tbroc. gov.tw

[12] Walls, A., Okumus, F., Wang, Y., and Kwun, D. (2011a). An epist emological view of consumer experiences. International Journal of Hospitality Management, 30(1), 10-12.

[13] World Economic Forum (2013). Travel and Tourism Competitiveness Report: Executive Summary, Switzerland: WEF.

[14] World Tourism Organization (2013). Tourism Highlights, 2011 edition, New York: UNWTO. 